\title{
Spheroplast Fusion as a Mode of Genetic Recombination in Mycobacteria
}

\author{
By NALIN RASTOGI, ${ }^{*}$ HUGO L. DAVID ${ }^{1}$ AND ELIE RAFIDINARIVO ${ }^{2}$ \\ ${ }^{1}$ Service de la Tuberculose et des Mycobactéries, Institut Pasteur, 25 Rue du Dr Roux, \\ 75015 Paris, France \\ ${ }^{2}$ Centre de Recherche de Biochimie et de Génétique Cellulaire du CNRS, 118 Route de \\ Narbonne, 31062 Toulouse Cedex, France
}

(Received 18 August 1982; revised 7 January 1983)

\begin{abstract}
Spheroplasts were prepared from two carotenoid pigment mutants of Mycobacterium aurum named $\mathrm{NgR}_{9}$ and $\mathrm{A}_{11}$, which were obtained by the chemical mutagenesis of the wild type strain $\mathrm{A}^{+}$with $N$-methyl- $N^{\prime}$-nitro- $N$-nitrosoguanidine. The carotenoid pigments and the $\alpha$ - and $\beta$ mycolic acids were taken as genetic markers and the recombinants were selected on the basis of their colour on Löwenstein-Jensen medium. Spheroplasts of the two mutants were mixed in a $1: 1$ ratio and were treated with $40 \%(\mathrm{w} / \mathrm{v})$ polyethylene glycol 6000 for $5 \mathrm{~min}$ at $37^{\circ} \mathrm{C}$. The frequency of $\mathrm{NgR}_{9} \times \mathrm{A}_{11}$ recombination in optimal conditions was about $2.5 \times 10^{-3}$. The recombinants selected on the basis of their carotenoid pigment profile were also tested for their $\alpha$ - and $\beta$-mycolic acids as a second genetic marker. The results were further confirmed by electron microscopy. The optimal conditions for spheroplast fusion as a mode of genetic recombination in $\boldsymbol{M}$. aurum are described.
\end{abstract}

\section{INTRODUCTION}

Very few reports on genetic transfer in mycobacteria have been published; the topic has been reviewed in detail by Grange $(1975,1982)$ and Šlosárek et al. (1978). According to these reports, optimal conditions under which genetic transfer would be reliable and reproducible have not yet been found. Limited success in genetic transfers has been achieved by conjugation in $\mathbf{M y c o -}$ bacterium smegmatis (Mizuguchi \& Tokunaga, 1971; Tokunaga et al., 1973; Mizuguchi, 1974; Mizuguchi et al., 1976). The only other mycobacterial species for which recombination has been attempted are Mycobacterium phlei and Mycobacterium tuberculosis, but mating strains were not found and attempts to induce mating competence in $M$. phlei by transferring fertility (F) plasmids from Escherichia coli were not successful (Koniček \& Koničkova-Radochová, 1975).

Transformation (Nordgard \& Imaeda, 1978) and transfection (Nakamura, 1970) have been reported but success has been very limited in this field, probably due to a lack of suitable recipient strains or to the complexity of the mycobacterial cell wall. Better results by transduction have been claimed (Redmond, 1970; Gelbart \& Juhasz, 1970; Sundar Raj \& Ramakrishnan, 1970; Jones \& David, 1972; Saroja \& Gopinathan, 1973). However, the transducing system of Gelbart \& Juhasz (1970) showed that up to $20 \%$ of the transfer activity was due to co-transfer of DNA. Because of the limited number of genes transferred, transduction can only be used for studying the fine structure of parts of bacterial genome, and would be unsuitable for the mapping of the bacterial genome.

Thus the genus Mycobacterium has played a very limited role in basic studies on molecular biology and genetics. According to Redmond (1970), the knowledge of genetics in mycobacteria in 1970 had reached only the stage that had been achieved in 1947 with E. coli. Because we had

Abbreviations: LJ medium, Löwenstein-Jensen medium; PEG, polyethylene glycol. 
already developed a method for spheroplast preparation from Mycobacterium aurum (Rastogi \& David, 1981), we looked at fusion as a mode of genetic recombination in mycobacteria.

Fusion as a tool of genetic recombination was first reported for plant protoplasts (Power et al., 1970; Carlson et al., 1972), followed by fungal protoplasts (Ferenczy et al., 1975; Anné \& Peberdy, 1976), Bacillus subtilis (Schaeffer et al., 1976; Gabor \& Hotchkiss, 1979), Bacillus megaterium (Fodor \& Alföldi, 1976; Fodor et al., 1978), different Streptomyces species (Hopwood et al., 1977; Hopwood \& Wright, 1978, 1979; Baltz, 1978; Godfrey et al., 1978; Ochi et al., 1979; Gumpert, 1980) and yeasts (van Solingen \& van der Plaat, 1977; Svoboda, 1978). The mechanism of fusion was recently studied electron microscopically by Frehel et al. (1979), and Gumpert (1980) has recently proposed a model for membrane alterations during fusion at the molecular level.

The above reports showed that $(a)$ genetic recombination by protoplast fusion permitted transfer of larger genome parts than did conventional methods, or transfer of entire genomes of two or more cells; $(b)$ genetic recombination at high frequency was possible even in bacteria for which conventional methods would not work; $(c)$ stable recombinants could be isolated after fusion, once wall regeneration was achieved. In this paper, we show that fusion of mycobacterial spheroplasts results in genetic recombination and describe the optimal conditions required for fusion in $M$. aurum.

\section{METHODS}

Organism and growth. Mycobacterium aurum $\mathrm{A}^{+}$(wild-type, yellow coloured) was from our own culture collection. Cells maintained on slants of Löwenstein-Jensen (LJ) medium were used. Two carotenoid pigment mutants, $A_{11}$ (a first-stage mutant, white, devoid of carotenoid pigments) and $\mathrm{NgR}_{9}$ (a brick red, second-stage mutant derived from $A_{13}$ ) were obtained by chemical mutagenesis of the original $A^{+}$strain (Lévy-Frébault \& David, 1979). Bacteria were grown as a shake culture in nutrient broth (Difco) at $37^{\circ} \mathrm{C}$. For carotenoid pigment studies, the bacteria were incubated for $12 \mathrm{~d}$ at $37^{\circ} \mathrm{C}$. For all other studies, the cells were harvested after 3 to $4 \mathrm{~d}$.

Spheroplast preparation and regeneration. Spheroplasts were prepared as reported earlier (Rastogi \& David, 1981). For spheroplast regeneration, appropriate dilutions of the spheroplast suspensions in $\mathrm{Tris} / \mathrm{HCl}$ buffer $(50 \mathrm{~mm}, \mathrm{pH} 7.0)$ containing $20 \% \mathrm{w} / \mathrm{v})$ sucrose were plated on LJ medium in Petri dishes and the colonies were counted after one week, once the counts were stabilized. The rate of spheroplast regeneration under our experimental conditions was about $10^{-1}$ for mutant $\mathrm{NgR}_{9}$ and about $1.7 \times 10^{-1}$ for mutant $\mathrm{A}_{11}$.

Spheroplast fusion. The $\mathrm{NgR}_{9}$ and $\mathrm{A}_{1}$, spheroplasts were mixed in a $1: 1$ ratio (approximately $10^{8}$ to $10^{9}$ spheroplasts capable of regeneration; rate of spheroplast reconversion being about $10^{-1}$ to $2 \times 10^{-1}$ ). They were treated with DNAase type 1 (Sigma) $\left(5 \mu \mathrm{g} \mathrm{ml}^{-1}\right)$ in the presence of $20 \%(\mathrm{w} / \mathrm{v})$ sucrose for $30 \mathrm{~min}$ at $37^{\circ} \mathrm{C}$, before treatment with polyethylene glycol (PEG). The two spheroplast types were sedimented together by centrifugation at $10000 \mathrm{~g}$ at room temperature, and 1 to $2 \mathrm{ml}$ of a prewarmed $\left(37^{\circ} \mathrm{C}\right)$ solution of $40 \%(\mathrm{w} / \mathrm{v})$ PEG 6000 in $50 \mathrm{mM}$ Tris $/ \mathrm{HCl}(\mathrm{pH} \mathrm{7.0)}$ was added to the pellet followed by gentle mixing. At this stage, aggregation of spheroplasts could be detected by phase-contrast microscopy in a thin layer of $2 \%(\mathrm{w} / \mathrm{v})$ agar. After incubation for $5 \mathrm{~min}$ (unless otherwise indicated) at $37^{\circ} \mathrm{C}$, the spheroplast suspension was diluted 10 -fold in Tris/ $\mathrm{HCl}$ buffer $(50 \mathrm{mM}, \mathrm{pH} \mathrm{7.0)}$ containing $20 \%(\mathrm{w} / \mathrm{v})$ sucrose and $5 \mu \mathrm{g}$ DNAase type $1 \mathrm{ml}^{-1}$. Centrifugation at this step was not necessary as PEG at $4 \%(\mathrm{w} / \mathrm{v})$ had no effect on spheroplast fusion. All serial dilutions were performed in the same buffer and appropriate dilutions were plated on $\mathrm{LJ}$ medium for recombinant selection. $\mathrm{Ca}^{2+}$ in concentrations from 10 to $100 \mathrm{~mm}$ has often been used in PEG-induced fusion experiments (Ochi et al., 1979; Gumpert, 1980); however, its presence was not necessary in fusion experiments with $M$. aurum.

Extraction and identification of carotenoid pigments. The harvested cells, suspended in a minimum volume of water, were extracted several times with chloroform/methanol $(1: 1, v / v)$. An equal volume of petroleum ether (b.p. 40 to $60^{\circ} \mathrm{C}$ ) was added to the extracts, the mixtures were vigorously stirred with a Vortex mixer, and the pigments were then allowed to partition. The epiphasic pigments were then purified by preparative TLC on aluminium strips precoated with silica gel $F_{254}$ (Merck). The solvent used was $2 \%(v / v)$ acetone in $n$-hexane. The pigments were tentatively identified by comparing their absorption spectra and chromatographic properties with published data (Goodwin, 1954; Davies, 1965; Lévy-Frébault \& David, 1979). The carotenoid content of the extracts was estimated at $450 \mathrm{~nm}$ (Liaaen-Jensen \& Jensen, 1971). To compare the $R_{F}$ values of different pigments, TLC was performed on silica gel G precoated plates (Merck).

Extraction and identification of fatty acids. The bacteria were grown in Middlebrook 7H9 medium (Difco), supplemented with $0.5 \%(\mathrm{w} / \mathrm{v})$ Casitone (Difco) and $1 \%(\mathrm{w} / \mathrm{v})$ glucose. The medium was dispensed in $250 \mathrm{ml}$ Erlenmeyer flasks ( $100 \mathrm{ml}$ per flask). The cultures were incubated at $37^{\circ} \mathrm{C}$ with agitation for one week and the cells were harvested by centrifugation at the end of their exponential phase of growth. 
Bacterial lipids were saponified by refluxing for $12 \mathrm{~h}$ in a mixture of ethanol/benzene/water $(5: 1: 1$, by vol.) containing $5 \%(\mathrm{w} / \mathrm{v}) \mathrm{KOH}$. After acidification, the mixture was washed with distilled water and was then concentrated under vacuum. The fatty acids were then methylated with diazomethane. The methyl esters were chromatographed on activated silica gel G plates (Merck), with a mixture of hexane/ether $(8: 2, v / v)$ as the solvent. The fatty acids were detected by spraying with a solution of $0.01 \%$ rhodamine $\mathrm{B}$ in $0.25 \mathrm{M}$-sodium phosphate. The definitive identification was made by co-chromatography with authentic standards.

The mycolic acids were characterized by mass spectroscopy on a Varian-Mat $311 \mathrm{~A}$ instrument. The electron energy was $70 \mathrm{eV}$, the source temperature was $250^{\circ} \mathrm{C}$ and the direct probe temperature was about $280{ }^{\circ} \mathrm{C}$. The methods used were the same as those described earlier (Promé et al., 1976; Asselineau \& Asselineau, 1978; Asselineau et al., 1981).

Electron microscopy. Spheroplasts were prefixed for $2 \mathrm{~h}$ at $4{ }^{\circ} \mathrm{C}$ with $1 \%(\mathrm{w} / \mathrm{v}$ ) glutaraldehyde (Sigma) in $0 \cdot 2 \mathrm{M}$ cacodylate buffer ( $\mathrm{pH} 6)$ containing $0.34 \mathrm{M}$-sucrose and $10 \mathrm{~mm}-\mathrm{Mg}^{2+}$. After centrifugation, the pellets were resuspended in $2.5 \%(\mathrm{w} / \mathrm{v})$ agar in nutrient broth. Small blocks were cut out and were fixed overnight $(18 \mathrm{~h})$ in $2.5 \%(w / v)$ glutaraldehyde in Michaelis-veronal buffer, washed twice with the same buffer, and postfixed with $1 \%$ $(\mathrm{w} / \mathrm{v}) \mathrm{OsO}_{4}$ and then with $1 \%(\mathrm{w} / \mathrm{v})$ uranyl acetate as reported earlier (Ryter \& Kellenberger, 1958). Dehydration was performed with acetone and embedding with Epon (Ladd Research Laboratories, U.S.A.). Sections $40 \mathrm{~nm}$ thick were cut with a diamond knife on a Sorval microtome, stained with lead citrate and observed in a Siemens Elmiscope 101 electron microscope.

The position of fusing cytoplasmic membranes was located by silver proteinate coloration, as applied earlier to mycobacteria (Rastogi et al., 1981, 1982).

\section{RESULTS}

\section{Recombinant selection and identification}

The character used for the preliminary selection of recombinants was the colour of the colonies formed on $\mathrm{LJ}$ medium. Mutants $\mathrm{NgR}_{9}$ and $\mathrm{A}_{11}$ formed brick red and white colonies respectively (the wild-type parental $\mathrm{A}^{+}$strain was orange-yellow). To establish if recombination between $\mathrm{NgR}_{9}$ and $\mathrm{A}_{11}$ mutants had taken place, mixtures of the respective spheroplasts (after PEG treatment, see below) were plated together and screened for yellow colonies. On plates we observed yellow-salmon coloured colonies with a frequency of $2.2 \times 10^{-3}$, and some sectorial colonies with a frequency of about $5 \times 10^{-5}$ (Table 1, Fig. 1). Yellow-salmon coloured colonies were cloned.

The results of TLC of isolated carotenoid pigments, and their absorption spectra, and also the analysis of mycolic acids, confirmed that the recombinants were different from the parental strains (Table 1), as they formed carotenoid pigments not found in the parental strains, and as the distribution of mycolic acids in the recombinants was also distinct from the parental strains.

TLC of the total fatty acid methyl esters of the wild-type $\mathrm{A}^{+}$strain revealed five spots: mycosanoate $\left(R_{F} 0.77\right)$, esters of common fatty acids $\left(R_{F} 0.72\right), \alpha$-mycolate $\left(R_{F} 0.44\right), \beta$-mycolate

Table 1. Recombination following fusion of $\mathrm{Ng} R_{9} \times A_{11}$ spheroplasts: distribution of mycolic acids and carotenoid pigments in M. aurum $A^{+}$(wild type), $N g R_{9}$ and $A_{11}$ mutants and three randomly chosen recombinants

\begin{tabular}{|c|c|c|c|c|c|c|c|c|c|}
\hline \multirow[b]{3}{*}{ Organism } & \multirow{3}{*}{$\begin{array}{c}\text { Colour } \\
\text { of } \\
\text { colonies }\end{array}$} & \multicolumn{6}{|c|}{ Carotenoid pigments } & \multirow{2}{*}{\multicolumn{2}{|c|}{ 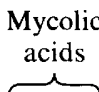 }} \\
\hline & & & & & Neuro- & Chloro- & & & \\
\hline & & Leprotene & $\alpha$-Carotene & Lycopene & sporene & bactene? & $\delta$-Carotene & $\alpha$ & $\beta$ \\
\hline $\mathrm{A}^{+}$ & $\begin{array}{c}\text { Orange- } \\
\text { yellow }\end{array}$ & + & + & + & + & \pm & \pm & + & + \\
\hline $\mathrm{NgR}_{9}$ & Brick red & - & - & + & + & - & + & + & - \\
\hline$A_{11}$ & White & - & - & - & - & - & - & + & + \\
\hline $\mathrm{R} 2$ & $\begin{array}{l}\text { Yellow- } \\
\text { salmon }\end{array}$ & - & + & + & + & - & + & + & + \\
\hline R20 & $\begin{array}{l}\text { Yellow- } \\
\text { salmon }\end{array}$ & - & - & + & + & + & - & + & + \\
\hline R27 & $\begin{array}{l}\text { Yellow- } \\
\text { salmon }\end{array}$ & - & + & + & + & - & - & + & + \\
\hline
\end{tabular}



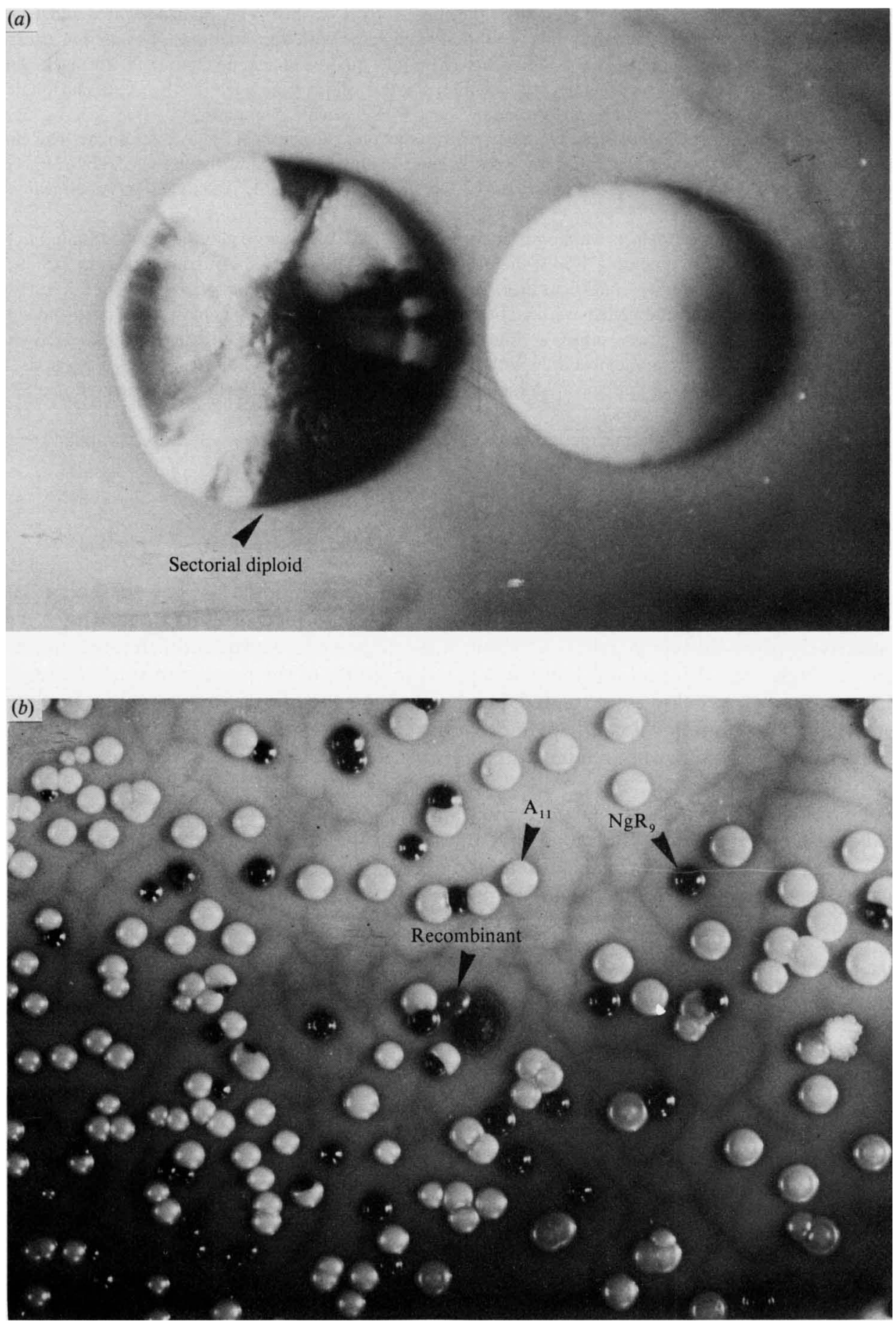

Fig. 1. Preliminary selection of diploid cells and recombinants after platings on LJ medium of PEGtreated $\mathrm{NgR}_{9} \times \mathrm{A}_{11}$ spheroplasts: (a) unstable diploids were found with a frequency of about $5 \times 10^{-5}$, and could be recognized by their typical sectorial colony phenotype; $(b)$ yellow-salmon coloured recombinants were found with a frequency of about $2 \cdot 2$ to $3 \cdot 5 \times 10^{-3}$. 
$\left(R_{F} 0 \cdot 33\right)$, dicarboxylic mycolate $\left(R_{F} 0 \cdot 17\right)$ and methyl carbinol $\left(R_{F} 0 \cdot 17\right)$. TLC of total fatty acid methyl esters of the mutants $\mathrm{NgR}_{9}$ and $\mathrm{A}_{11}$ showed that while $\mathrm{A}_{11}$ had the same profile as $\mathrm{A}^{+}$, $\mathrm{NgR}_{9}$ was deficient in $\beta$-mycolate. The possibility that the $\beta$-mycolate could have been masked by $\gamma$-mycolate (i.e. $\omega$-methylcarbinol esters of dicarboxylic mycolates) was eliminated by verifying that $\gamma$-mycolates were fully hydrolysed in our experimental conditions.

The recombinants obtained were analysed for their fatty acid content. They all contained $\beta$ mycolates as did strains $A^{+}$and $A_{11}$, in addition to other fatty acids. These results showed that some form of genetic exchange took place during $M$. aurum spheroplast fusion; however, a true wild-type phenotype among the recombinant clones could not be found (Table 1). In previous studies on reversion rates of the individual mutants $\mathrm{NgR}_{9}$ and $\mathrm{A}_{11}$ (Lévy-Frébault \& David, 1979; V. Lévy-Frébault, personal communication), as well as during our own control experiments, no revertants were found, possibly because each strain was a double or triple mutant. This observation is important in more than one aspect: firstly the yellow-salmon coloured colonies observed at frequencies greater than $10^{-3}$ were not revertants of the individual mutants but a result of genetic exchange, and secondly it would also explain the absence of recombinant clones with a wild-type phenotype. Since fusions of more than two cells can occur, presumably resulting in various ploidy levels, the results are difficult to interpret at the genetic level.

In addition to the yellow-salmon coloured recombinants, we also observed a few sectorial colonies (Fig. 1, Table 2). When the sectored colonies were resuspended in RVB 10 medium (Difco) and were successively transferred in the same medium and plated on LJ medium, we observed that the frequency of the sectored colony types decreased rapidly in the colony population from $6 \times 10^{-2}$ to $8 \times 10^{-2}$ to $10^{-5}$ or even less after three transfers (Fig. 2). These data showed that the sectored colonies were developed from diploid or polyploid organisms. However, the diploidy or polyploidy appeared unstable as it segregated rapidly after a few transfers on a proper growth medium. It would be logical to expect that such sectored colonies would generate recombinant clones on subculture, even if at a low frequency. However, in our own studies we did not search for these as it would have required a large number of dilution platings. Instead, we attempted to verify whether the diploidy or polyploidy in the above case was stable.
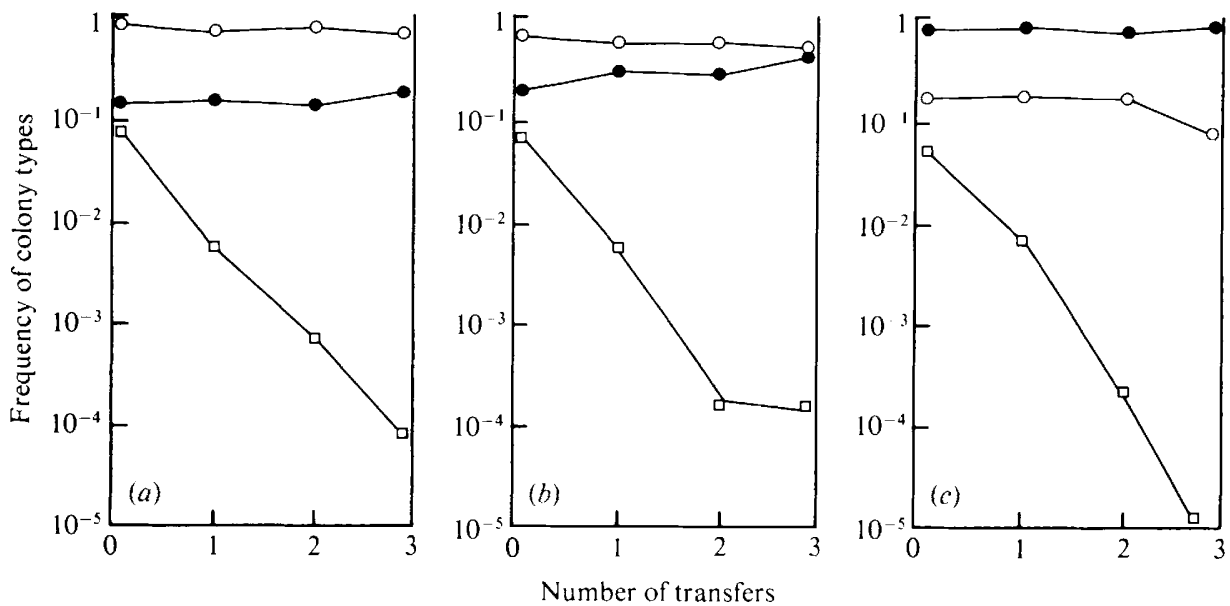

Fig. 2. Segregation of diploid bacteria (sectorial colonies) after successive transfers in RVB 10 medium; $(a),(b)$ and $(c)$ show the segregation of the sectorial colonies 2,3 and 4 respectively (see Table 2). During each transfer about $10^{8}$ initial bacteria were grown to give about $10^{10}$ c.f.u. 0 on the transfer scale gives the frequency of different colony types among the initial diploid colonies. The data shown on this scale were obtained by direct platings of the above colonies on $\mathrm{LJ}$ medium (see Table 2)., $\mathrm{NgR}_{\text {, }}$ cells; $O, A_{11}$ cells: $\square$, diploid cells. 


\section{Table 2. Segregation of diploid bacteria (sectorial colonies)}

Sectorial colony 1 is shown in Fig. $1(a)$; sectorial colonies 2, 3 and 4 were obtained from the platings of original colony 1 shown in Fig. $1(a)$ and their segregation was studied after successive transfers in RVB 10 medium (Fig. 2). The results show the number of colonies with different phenotypes after direct plating of the indicated sectorial colonies on $\mathbf{L J}$ medium.

\begin{tabular}{cccc} 
Sectorial $\begin{array}{c}\text { Phenotype of colony population } \\
\text { colony }\end{array}$ & \multicolumn{2}{c}{ Phite $\left(\mathrm{A}_{11}\right)$} & Sectorial \\
1 & 700 & 500 & 48 \\
2 & 18 & 142 & 14 \\
3 & 50 & 165 & 16 \\
4 & 256 & 50 & 17
\end{tabular}

According to these data, spheroplast fusion in $M$. aurum resulted in genetic exchanges. Some of the resulting fusion products were transient diploids or polyploids, while in other cases, stable recombinants could be isolated. However, none of the recombinants isolated had a true wildtype phenotype.

\section{Effect of PEG-treatment on spheroplast regeneration and fusion}

The effects of PEG treatment were observed under different experimental conditions to find optimal conditions for $M$. aurum spheroplast regeneration and fusion. In all these experiments, the number of spheroplasts regenerated without any treatment was taken as $100 \%$ and all other values are expressed as the percentage of the spheroplasts regenerated. The fusion frequencies are calculated taking into account only the regenerated spheroplasts. The conditions tested were the following: (a) effect of different molecular weights of PEG, ranging from 200 to 20000 (Fig. 3 ); (b) effect of different concentrations of PEG-6000 (Fig. 4); (c) effect of the duration of treatment with $40 \%(\mathrm{w} / \mathrm{v})$ PEG-6000 (Fig. 5); (d) effect of $\mathrm{pH}$ ranging from 3 to 9 , during treatment with or without $40 \%$ (w/v) PEG-6000 for 5 min at $37^{\circ} \mathrm{C}$ (Fig. 6).

(a) All PEG solutions of molecular weights ranging from 200 to 20000 were prepared at $40 \%$ $(w / v)$ in distilled water (except PEG-20000 which was used only at $30 \%$ due to its high viscosity). The time of PEG treatment was $5 \mathrm{~min}$ at $37^{\circ} \mathrm{C}$. As shown in Fig. 3, the fusion was optimal with PEG-6000, which resulted in up to $2 \cdot 2 \times 10^{-3}$ recombinants. Increasing the molecular weight of PEG caused clumping of spheroplasts and decreased the number of regenerated spheroplasts.

(b) Figure 4 shows the effect of PEG-6000 in concentrations ranging from 0 to $60 \%(\mathrm{w} / \mathrm{v})$ on spheroplast regeneration and recombinant frequency. The time of PEG treatment was 5 min at $37^{\circ} \mathrm{C}$. Though recombinant frequency was as high as $3.5 \times 10^{-3}$ with $50 \%$ PEG- 6000 , there was high killing among spheroplasts with concentrations above $40 \%$.

(c) When spheroplasts were treated with $40 \%$ (w/v) PEG-6000 at $37^{\circ} \mathrm{C}$ for times ranging from 5 to $60 \mathrm{~min}$ (Fig. 5), the recombination frequency increased from $4 \times 10^{-4}$ at time 0 (measured immediately after PEG addition) to about $2.2 \times 10^{-3}$ within 5 min of treatment. Longer treatments did not significantly increase the recombination frequency but caused a significant decrease of the total regenerated spheroplasts.

(d) Figure 6 shows the effect of $\mathrm{pH}$ ranging from 3 to 9 during treatment with $40 \%(\mathrm{w} / \mathrm{v})$ PEG6000 for $5 \mathrm{~min}$ at $37^{\circ} \mathrm{C}$. For this experiment the PEG solution was prepared either in $50 \mathrm{mM}$ citrate buffer ( $\mathrm{pH}$ range from 3 to 6 ) or in $50 \mathrm{~mm}$-Tris/HCl buffer ( $\mathrm{pH}$ range from 7 to 9 ) (all $\mathrm{pH}$ values at $20^{\circ} \mathrm{C}$ ). The serial silutions were done in similar $\mathrm{pH}$ conditions and were then plated on $\mathrm{LJ}$ medium. The results obtained indicate that $M$. aurum spheroplasts were more tolerant of alkaline than acidic conditions. However, both the spheroplast regeneration and recombination frequency were maximal at $\mathrm{pH} 6$.

\section{Ultrastructural observations}

Figures 7 and 8 show the ultrastructure of $\mathrm{NgR}_{9} \times \mathrm{A}_{11}$ spheroplasts after PEG treatment. An agglutination of the spheroplasts could be observed (Fig. 7). As up to $3 \times 10^{-2}$ spheroplasts 


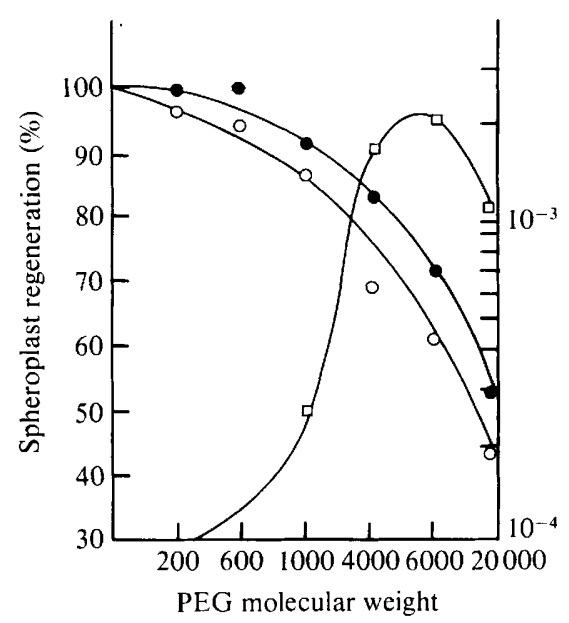

Fig. 3

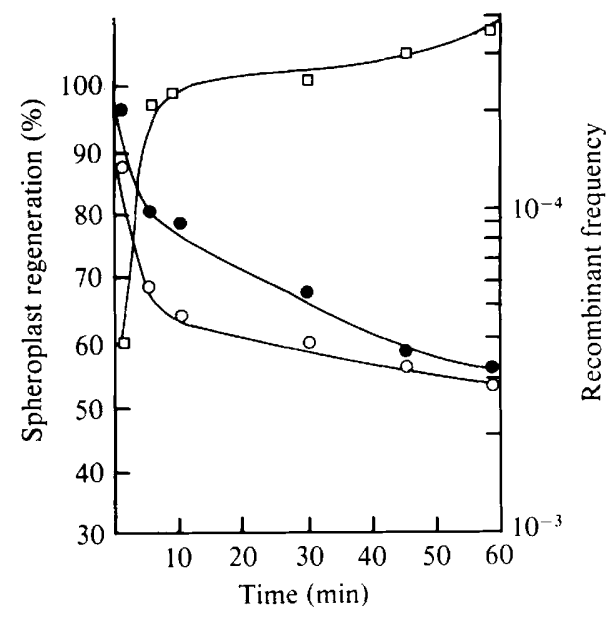

Fig. 5

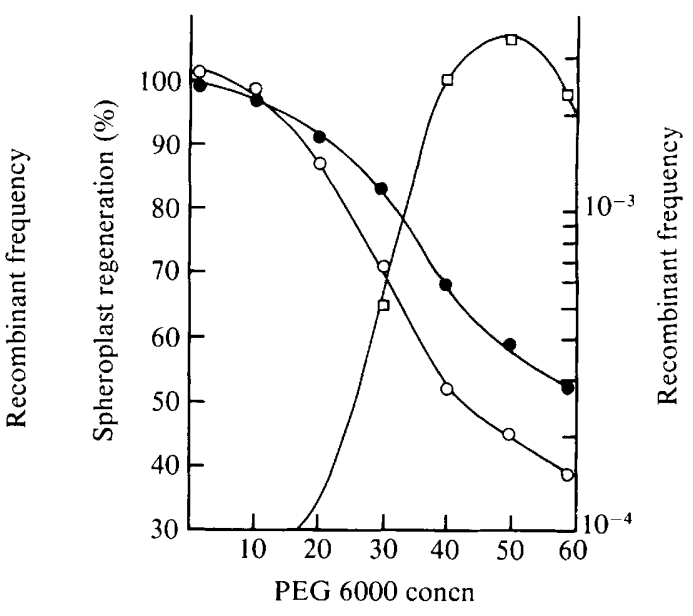

Fig. 4

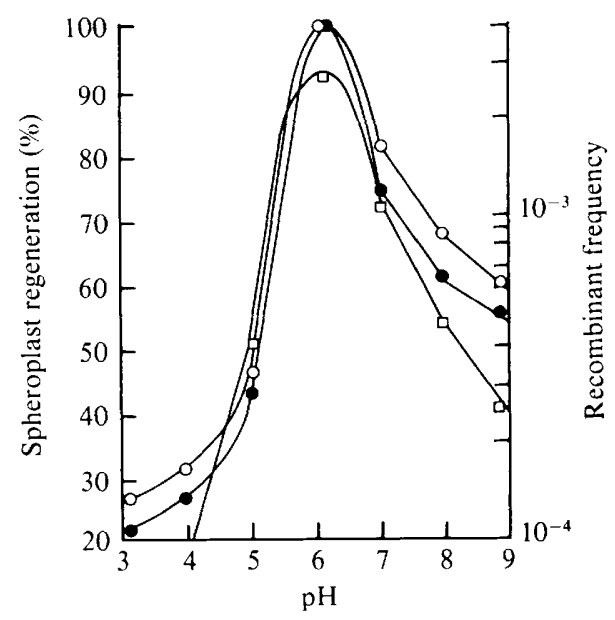

Fig. 6

Fig. 3. Effect of different molecular weights of PEG on spheroplast regeneration and recombination frequency. PEG of molecular weights ranging from 200 to 20000 was used at $40 \%(\mathrm{w} / \mathrm{v})$; treatment was for $5 \mathrm{~min}$ at $37^{\circ} \mathrm{C}$. $\mathrm{O}, \mathrm{NgR}_{9}$ spheroplast regeneration; $O, \mathrm{~A}_{1 \mathrm{i}}$, spheroplast regeneration: $\square$, recombinant frequency.

Fig. 4. Effect of different concentrations of PEG-6000 on spheroplast regeneration and recombinant frequency. PEG-6000 was used in concentrations from $10 \%(\mathrm{w} / \mathrm{v})$ to $60 \%(\mathrm{w} / \mathrm{v})$; treatment was for 5 min at $37^{\circ} \mathrm{C}$. $\mathrm{NgR}_{9}$ spheroplast regeneration; $\mathrm{O}, \mathrm{A}_{11}$ spheroplast regeneration; $\square$, recombinant frequency.

Fig. 5. Effect of the duration of PEG treatment on spheroplast regeneration and recombination frequency. $\mathrm{NgR}_{9} \times \mathrm{A}_{11}$ spheroplasts were treated with $\mathrm{PEG}-6000$ for different times ranging from 0 to 60 min at $37^{\circ} \mathrm{C}$., $\mathrm{NgR}_{9}$ spheroplast regeneration; $O, \mathrm{~A}_{11}$ spheroplast regeneration; $\square$, recombinant frequency.

Fig. 6. Effect of $\mathrm{pH}$ during $\mathrm{PEG}$ treatment of $\mathrm{NgR}_{9} \times \mathrm{A}_{11}$ spheroplasts. PEG solutions $(40 \%$ w/v) were prepared either in $50 \mathrm{mM}$-citrate buffer ( $\mathrm{pH}$ range from 3 to 6 ) or in $50 \mathrm{~mm}$-Tris/ $\mathrm{HCl}$ ( $\mathrm{pH}$ range from 7 to 9). Spheroplasts were treated for $5 \mathrm{~min}$ at $37^{\circ} \mathrm{C}$., $\mathrm{NgR}_{9}$ spheroplast regeneration; $\mathrm{O}, \mathrm{A}_{11}$ । spheroplast regeneration; $\square$, recombinant frequency. 


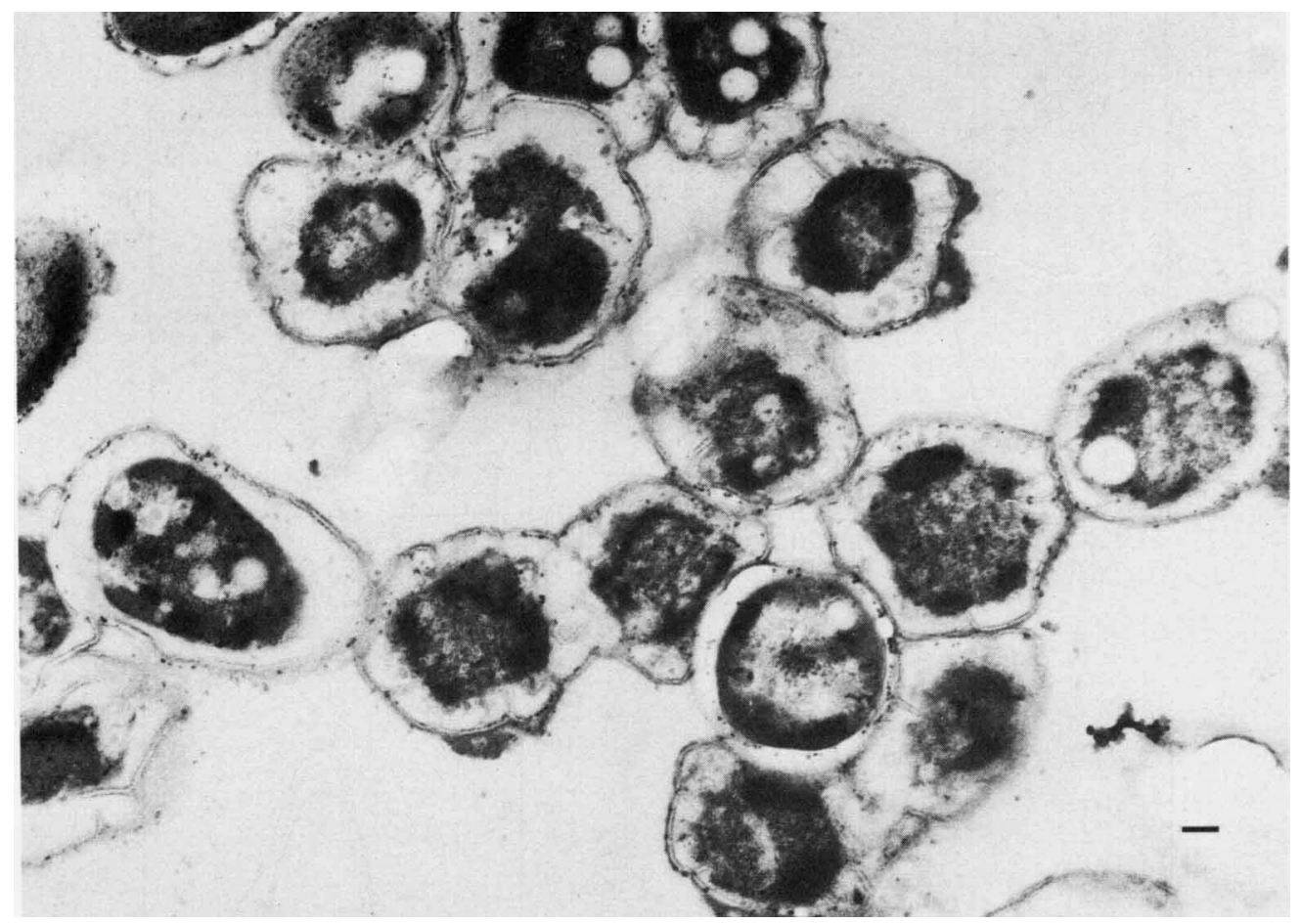

Fig. 7. Ultrastructure of PEG-treated $\mathrm{NgR}_{9} \times \mathrm{A}_{11}$ spheroplasts: after the addition of $40 \%(w / v) P E G-$ 6000 to the spheroplast mixture, an immediate clumping could be observed. The bar marker represents $100 \mathrm{~nm}$.

showed fusion events in electron microscopy compared to about $2.2 \times 10^{-3}$ recombinants isolated, it appeared that only about one fusion event in 10 was able to give the desired recombinant.

Figures $8(a),(b)$ and $(c)$ show fusing spheroplasts at different stages; Fig. $8(a)$ shows two spheroplasts sticking to each other with a contact zone still maintained. Sometimes a contact zone was associated with the formation of vacuoles (Fig. 8b). Figure 8(c) shows two perfectly fused spheroplasts, and only such fusion events should be considered as representative of the fusion event. Figure $8(d)$ might account for relatively rare events of fusion between more than two spheroplasts and would probably result in polyploidy. Similar multiple fusion events have been reported earlier from Bacillus subtilis (Frehel et al., 1979). Figures $8(e),(f),(g)$ and $(h)$ show different stages of spheroplast fusion at the contact zone level, ranging from a simple clumping (Fig. 8e) to complete fusion (Fig. $8 h$ ). The examples in Figs $8(f)$ and $(g)$ are probably intermediate stages between the start and the end of the fusion process.

\section{DISCUSSION}

Our data show that when spheroplasts of two carotenoid pigment mutants of $M$. aurum $\mathrm{A}^{+}$ were mixed together in the presence of $40 \%(\mathrm{w} / \mathrm{v})$ PEG-6000, recombinants could be isolated with a frequency of $2 \cdot 2 \times 10^{-3}$. Though we did not find recombinants with PEG-200 and PEG600 , this was due to a lower recombination frequency rather than to the complete absence of recombinants. This was confirmed by the fact that in our control experiments without PEG treatment, fusion could be produced at very low frequencies (less than $10^{-5}$ ) by high-speed centrifugation alone of the $\mathrm{NgR}_{9} \times \mathrm{A}_{11}$ spheroplasts at $\mathrm{pH}$. This certainly was not a transformation event as DNAase type $1\left(5 \mu \mathrm{g} \mathrm{ml}^{-1}\right)$ was present during the centrifugation and 

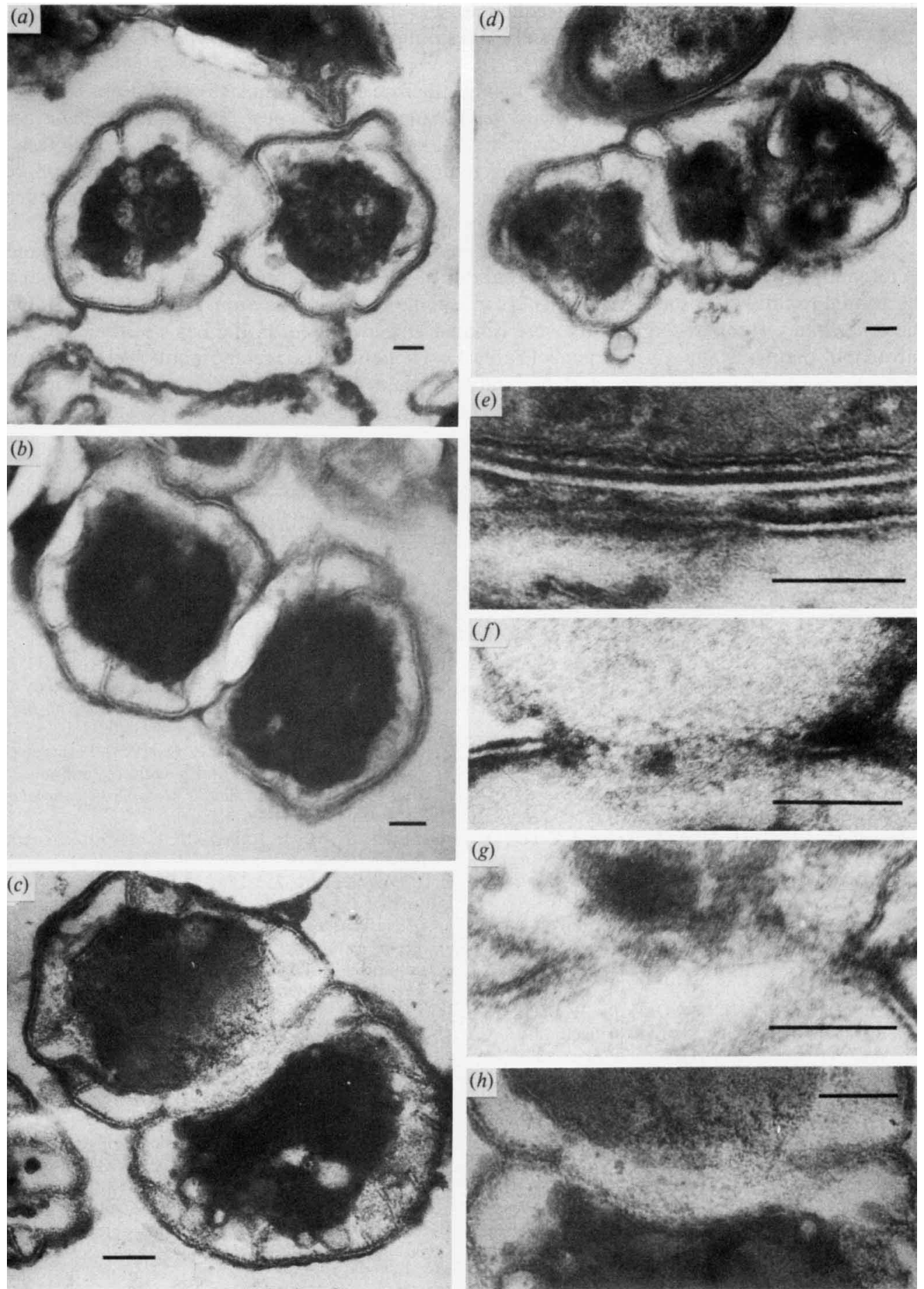

Fig. 8. Ultrastructure of fusing spheroplasts at different stages: $(a)$ two spheroplasts clumping to each other with a well-maintained contact zone; (b) sometimes vacuoles could be observed at the contact zone level; $(c)$ two spheroplasts which seem to be perfectly fused to each other; $(d)$ a possible multiple fusion event; $(e-h)$ different stages of fusion at the contact zone level, ranging from simple clumping $(e)$ to complete fusion $(h)$. The bar markers represent $100 \mathrm{~nm}$. 
plating steps. Optimal recombination frequencies were found when the spheroplasts were mixed in a $1: 1$ ratio and centrifuged together, and the resulting pellet was treated with $40 \%$ (w/v) PEG6000 at $\mathrm{pH} 6$ for $5 \mathrm{~min}$ at $37^{\circ} \mathrm{C}$.

The ultrastructural examination of the fusing spheroplasts gave images compatible with our data as well as with those found earlier with Bacillus subtilis (Frehel et al., 1979) and Streptomyces hygroscopiscus (Gumpert, 1980). However, unlike Bacillus or Streptomyces protoplasts, mycobacterial spheroplasts contain few wall remnants. This observation suggests that unlike Escherichia coli spheroplasts (Lévy, 1978), which do not yield recombinants due to the presence of the outer layer, mycobacterial wall remnants do not inhibit fusion.

Spheroplast fusion in $M$. aurum resulted in yellow-salmon coloured recombinants and sectored diploids. The diploids were apparent due to a typical sectorial colony type (Fig. 1) and segregated rapidly after successive transfers in a suitable growth medium (Fig 2, Table 2). On the other hand, stable recombinants were isolated and identified on the basis of their colour, carotenoid pigments and mycolic acids (Table 1). Though all the recombinants were different from the parental strains $\mathrm{NgR}_{9}$ and $\mathrm{A}_{11}$, none of them formed leprotene, one of the major pigments formed by the wild-type $\mathrm{A}^{+}$strain (Lévy-Frébault \& David, 1979), possibly because $\mathrm{NgR}_{9}$ and $\mathrm{A}_{11}$ were double or triple mutants.

We thank L. G. Chevance and H. Ohayon, Station Centrale du Microscopie Electronique, Institut Pasteur, and A. Ryter, C. Frehel, R. Daty and J. C. Bénichou, Unité de Microscopie Electronique, Institut Pasteur, for helping with ultrastructural studies. This investigation was supported by grants from the Institut National de la Santé et de la Recherche Médicale (INSERM), France.

\section{REFERENCES}

Anné, J. \& Peberdy, J. F. (1976). Induced fusion of fungal protoplasts following treatment with polyethylene glycol. Journal of General Microbiology $\mathbf{9 2}$, 413-417.

Asselineau, C. \& Asselineau, J. (1978). Lipids spécifiques des mycobactéries. Annales de microbiologie 129A, 49-69.

Asselineau, C., Clavel, S., Clément, F., Daffé, M., David, H., Lanéelle, M. A. \& Promé, J. C. (1981). Constituants lipidiques de Mycobacterium leprae isolé de tatou infecté expérimentalement. Annales de microbiologie 132A, 19-30.

BALTZ, R. H. (1978). Genetic recombination in Streptomyces fradiae by protoplast fusion and cell regeneration. Journal of General Microbiology 107, 93-102.

Carlson, P. S., Smith, H. H. \& Dearing, R. D. (1972). Parasexual interspecific plant hybridization. Proceedings of the National Academy of Sciences of the United States of America 69, 2292-2294.

DAviEs, B. H. (1965). Analysis of carotenoid pigments. In Chemistry and Biochemistry of Plant Pigments, pp. 489-532. Edited by T. W. Goodwin. London: Academic Press.

Ferenczy, L., KeVeI, F. \& Szegedi, M. (1975). High frequency fusion of fungal protoplasts. Experientia 31, $1028-1030$

FODOR, K. \& ALFÖLDI, L. (1976). Fusing of protoplasts of Bacillus megaterium. Proceedings of the National Academy of Sciences of the United States of America 73, 2147-2150.

Fodor, K., Demiri, E. \& Alföldi, L. (1978). Polyethylene glycol induced fusion of heat-inactivated and living protoplasts of Bacillus megaterium. Journal of Bacteriology 135, 68-70.
Frehel, C., Lheritier, A. M., Sanchez-Rivas, C. \& SCHAEFFER, P. (1979). Electron microscopic study of Bacillus subtilis protoplast fusion. Journal of Bacteriology 137, 1354-1361.

Gabor, M. H. \& HotchKiss, R. D. (1979). Parameters governing regeneration and genetic recombination after fusion of Bacillus subtilis protoplasts. Journal of Bacteriology 137, 1346-1353.

Gelbart, S. M. \& Juhasz, S. E. (1970). Genetic transfer in Mycobacterium phlei. Journal of General Microbiology 64, 253-254.

Godfrey, O., Ford, L. \& Huber, M. L. (1978). Interspecies matings of Streptomyces fradiae with Streptomyces bikiniensis mediated by conventional and protoplast fusion techniques. Canadian Journal of Microbiology 24, 994-997.

Goodwin, T. W. (1954). Carotenoids: their Comparative Biochemistry. New York: Chemical Publishing Company.

Grange, J. M. (1975). The genetics of mycobacteria and mycobacteriophages - a review. Tubercle 56, $227-238$.

GRANGE, J. M. (1982). The genetics of mycobacteria and mycobacteriophages. In The Biology of the Mycobacteria, vol. 1, pp. 309-351. Edited by C. Ratledge \& J. Stanford. London: Academic Press.

GuMPERT, J. (1980). Electron microscopic analysis of protoplast fusion in Streptomyces hygroscopicus and consideration on structural alterations in fusing membranes. Archives of Microbiology 126, 263269.

HOPWOOD, D. A. \& WRIGHT, H. M. (1978). Bacterial protoplast fusion: recombination in fused protoplasts of Streptomyces coelicolor. Molecular and General Genetics 162, 307-317. 
Hopwood, D. A. \& Wright, H. M. (1979). Factors affecting recombinant frequency in protoplast fusion of Streptomyces coelicolor. Journal of General Microbiology 111, 137-143.

Hopwood, D. A., Wright, H. M., BibB, M. J. \& CoHEN, S. N. (1977). Genetic recombination through protoplast fusion in Streptomyces. Nature, London 268, 171-174.

Jones, W. D. \& David, H. L. (1972). Preliminary observations on the occurrence of a streptomycin Rfactor in Mycobacterium smegmatis ATCC 607. Tubercle 53, 35-42.

KoníČEK, J. \& KoníČKova-RADOChová, M. (1975). Possibilities of the conjugation process in mycobacteria. Folia microbiologica 23, 261-271.

LÉvy, C. (1978). Etude génétique et cytologique de la fusion cellulaire chez Bacillus subtilis et Escherichia coli. Thèse de Doctorat de $3^{\circ}$ Cycle, Université ParisSud, France.

LÉvy-FrébaUlT, V. \& David, H. L. (1979). Mutations affecting pigment synthesis in Mycobacterium aurum. Journal of General Microbiology 115, 317-323.

LiaAen-Jensen, S. \& Jensen, A. (1971). Quantitative determination of carotenoids in photosynthetic tissues. Methods in Enzymology 23, 586-602.

MizuguchI, Y. (1974). Effect of ultraviolet-sensitive mutants on gene inheritance in mycobacterial matings. Journal of Bacteriology 117, 914-916.

Mizuguchi, Y. \& ToKunaGa, T. (1971). Recombination between Mycobacterium smegmatis strains Jucho and Lacticola. Japanese Journal of Microbiology 15, 359-366.

Mizuguchi, Y., Suga, K. \& Tokunaga, T. (1976). Multiple mating types of Mycobacterium smegmatis. Japanese Journal of Microbiology 20, 435-443.

NaKamuRA, R. M. (1970). Transfection of Mycobacterium smegmatis in an acidic medium. In Host Virus Relationships in Mycobacterium, Nocardia and Actinomyces, pp. 166-178, Edited by S. E. Juhasz \& G. Plummer. Springfield, Illinois: Charles C. Thomson.

Nordgard, M. \& Imaeda, T. (1978). Physiological factors involved in the transformation of $\mathbf{M y c o}$ bacterium smegmatis. Journal of Bacteriology 133, 1254-1262.

OCHI, K., Нiтchсоск, М. J. М. \& KaTz, E. (1979). High frequency fusion of Streptomyces parvulus or Streptomyces antibioticus protoplasts induced by polyethylene glycol. Journal of Bacteriology 139, 984992.

Power, J. B., Cummins, S. E. \& Cocking, E. C. (1970). Fusion of isolated plant protoplasts. Nature, London 225, 1016-1018.
Promé, J. C., Lacave, C., Ahibo-Coffy, A. \& Savagnac, A. (1976). Séparation et étude structurale des espèces moléculaires de monomycolates et de dimycolates de $\alpha$-D-tréhalose présents chez $\mathrm{Myco}$ bacterium phlei. European Journal of Biochemistry 63, 543-552.

RaSTOGI, N. \& DAVID, H. L. (1981). Ultrastructure and chemical studies on wall-deficient forms, spheroplasts and membrane vesicles from Mycobacterium aurum. Journal of General Microbiology 124, 71-79.

Rastogi, N., Frehel, C., Ryter, A., Ohayon, H., Lesourd, M. \& David, H. L. (1981). Multiple drug resistance in Mycobacterium avium: is the wall architecture responsible for exclusion of antimicrobial agents? Antimicrobial Agents and Chemotherapy 20, 666-677.

Rastogi, N., Frehel, C., Ryter, A. \& David, H. L. (1982). Comparative ultrastructure of $\mathrm{Myco}$ bacterium leprae and $M$. avium grown in experimental hosts. Annales de microbiologie 133B, 109128.

REDMOND, W. B. (1970). Genetic studies on auxotrophic strains of atypical mycobacteria. Bulletin of the International Union against Tuberculosis 43, 214 216.

Ryter, A. \& Kellenberger, E. (1958). Etude au microscope électronique des plasmas contenant de l'acide déoxyribonucléique. I. Les nucléotides de bactéries en croissance. Zeitschrift für Naturforschung 13, 597-605.

SaroJa, D. \& Gopinathan, K. P. (1973). Transduction of isoniazid susceptibility-resistance and streptomycin resistance in mycobacteria. Antimicrobial Agents and Chemotherapy 4, 643-645.

SCHAEFFer, P., CAMI, B. \& Hotchkiss, R. D. (1976). Fusion of bacterial protoplasts. Proceedings of the National Academy of Sciences of the United States of America 73, 2151-2155.

ŠlosáREK, M., KoníčKova-RADOChová, M. \& KoNíČEK, J. (1978). Genetic transfers in mycobacteria. Folia microbiologica 23, 140-151.

van Solingen, P. \& van der PlaAt, J. B. (1977). Fusion of yeast spheroplasts. Journal of Bacteriology 130, 946-947.

Sundar RaJ, C. V. \& Ramakrishnan, T. (1970). Transduction in Mycobacterium smegmatis. Nature, London 228, 280-281.

SvoBODA, A. (1978). Fusion of yeast protoplast induced by polyethylene glycol. Journal of General Microbiology 109, 169-175.

Tokunaga, T., Mizuguchi, Y. \& Suga, K. (1973). Genetic recombination in mycobacteria. Journal of Bacteriology 113, 1104-1111. 